Article

\title{
Prognostic Role of the Red Blood Cell Distribution Width (RDW)in Hodgkin Lymphoma
}

\author{
Ines Herraez 1,2,3 ${ }^{\mathbb{D}}$, Leyre Bento ${ }^{2,3}$, Raquel Del Campo ${ }^{1,2}$, Adriana Sas 2,3 , Rafael Ramos ${ }^{2,4}$, \\ Javier Ibarra ${ }^{2,5}$, Francesc Mestre ${ }^{2,6}$, Regina Alemany ${ }^{2,7}$, Joan Bargay ${ }^{1,2}$, Antonia Sampol ${ }^{2,3}$ and \\ Antonio Gutierrez $2,3, *$ (D) \\ 1 Department of Hematology, Son Llatzer University Hospital, 07198 Palma de Mallorca, Spain; \\ ines.herraez@hsll.es (I.H.); rcampo@hsll.es (R.D.C.); jbargay@hsll.es (J.B.) \\ 2 Health Research Institute of the Balearic Islands (IdISBa-IUNICS), 07120 Palma de Mallorca, Spain \\ 3 Department of Hematology, Son Espases University Hospital, 07120 Palma de Mallorca, Spain; \\ leyre.bento@ssib.es (L.B.); adrianasas95@gmail.com (A.S.); antonia.sampolm@ssib.es (A.S.) \\ 4 Department of Pathology, Son Espases University Hospital, 07120 Palma de Mallorca, Spain; \\ rafaelf.ramos@ssib.es \\ 5 Department of Pathology, Son Llatzer University Hospital, 07198 Palma de Mallorca, Spain; jibarra@hsll.es \\ 6 Department of Radiotherapy, Son Espases University Hospital, 07120 Palma de Mallorca, Spain; \\ franciscoj.mestre@ssib.es \\ 7 Department of Biology, University of Balearic Islands, 07122 Palma de Mallorca, Spain; \\ regina.alemany@uib.es \\ * Correspondence: antoniom.gutierrez@ssib.es; Tel.: +34-(8)-7120-5000 (ext. 65115)
}

Received: 27 September 2020; Accepted: 1 November 2020; Published: 4 November 2020

check for updates

Simple Summary: The red blood cell distribution width (RDW) increasesin inflammatory conditions and is described as having a prognostic rolein different types of cancer. As Hodgkin lymphoma (HL) has a proinflammatory background, we aim to study the prognostic role of RDWin HL. We report in a large retrospective series of homogenously treated HL, for the first time, that RDW is a simple, cheap, and easily available prognostic factorin HL, that identifies a group with worse EFS, OS, and a higher potential incidence of secondary malignancies. RDW seems to be related to most adverse prognostic factorsin HL and this may make RDW a good candidate to be includedin current or new prognostic scores for HL.

Abstract: The red blood cell distribution width (RDW) is a parameter available from an automated blood count, which measures the degree of heterogeneity of erythrocyte volume and increasesin inflammatory conditions. The prognostic role of RDW has been describedin different types of cancers. Hodgkin lymphoma (HL) is a hematological malignancy, known to have a proinflammatory background. We aim to study the prognostic role of RDWin HL. We retrospectively analyzed 264 patients with HL from two hospitalsin the Balearic Islands between 1990 and 2018. Higher levels of RDW were independently related to anemia, B-symptoms, and low albumin. In age $\geq 45$ years, the presence of lymphopenia and higher RDW were independently associated with worse event-free survival (EFS) and overall survival (OS). Long-term incidence of secondary malignancies was significantly higherin patients with higher RDW, particularly lung cancer. In conclusion, we report for the first time that RDW is a simple, cheap, and easily available prognostic factorin HL that identifies a group with worse EFS, OS, and a higher potential incidence of secondary malignancies. RDW seems to be related to most adverse prognostic factorsin HL, making RDW an excellent candidate to be includedin prognostic scores for HL.

Keywords: Hodgkin lymphoma; RDW; risk factors; survival; secondary malignancies 


\section{Introduction}

Hodgkin lymphoma (HL) is a hematological malignancy characterized by few neoplastic cells called Reed-Sternberg inside an inflammatory microenvironment [1]. Standard therapy regimens cure approximately $80 \%$ of patients, but the other $20 \%$ will require salvage therapy [2]. Identifying factors that could improve the early detection of these refractory patients is very important to improve risk stratification and individualize treatment [3].

The red blood cell distribution width (RDW) is a simple blood test parameter that reflects the size diversity of red blood cells (anisocytosis)in peripheral blood and traditionally was used to study anemias [4]. In the last decade, higher levels of this parameter have been described as an adverse prognostic factorin cardiovascular diseases, inflammation, and cancer [5-11].

In cancer patients, higher values of RDW could be associated with a higher degree of inflammation. Increased levels of cytokines may modify iron metabolism by increasing levels of hepcidin and oxidative stress. Simultaneously, erythropoietin production is reduced, resultingin more anisocytosis and higher values of RDW [12,13].

Notably, RDW has been reported to have a prognostic rolein several lymphoproliferative diseases, such as chronic lymphocytic leukemia (CLL), diffuse large B-cell lymphoma (DLBCL), mantle cell lymphoma (MCL), or multiple myeloma [5,14-22]. Several groups recently proposed the inclusion of RDWin prognostic scoresin DLBCL [23,24].

However, there are scarce data for HL, where a proinflammatory background is a key eventin pathogenesis and physiopathology [25]. We aim to analyze the potential prognostic role of RDW in HL.

\section{Results}

\subsection{Patient Characteristics}

A total number of 264 patients with classic HL homogeneously treated with ABVD +/- RT were retrospectively analyzed at the time of diagnosis, at Son Espases $(n=165)$ and Son Llatzer ( $n=99)$ University Hospitalsin the Balearic Islands, between 1990 and 2018. The presenting features of the patients are shownin Table 1. The median age was 37 years (14-83 years), $52 \%$ of patients had an advanced stage, $16 \%$ had bulky disease, $28 \%$ had an Eastern Cooperative Oncology Group Performance Status (ECOG PS) $>1$, and $19 \%$ had an IPS $>3$. All prognostic factors of IPS are also shownin Table 1.

\subsection{Analysis of the Prognostic Role of RDW}

As shownin Table 1, the median RDWin the cohort was 13.9 (range, 10.6-23.9). To evaluate the ability of RDWin predicting a worse outcome, we considered the progression or death of any cause. As normal values changed with the center and the time, we standardized the values as a ratio of the upper normal valuein each center and time. Using a ROC analysis, we obtained an optimal cutoff of 0.95 of sRDW with an area under the curve of $0.64($ C195\%: $0.57-0.71)(p=0.001)$ (Figure 1).

\subsection{RDW and Main Prognostic Factorsin HL}

Additionally, we studied the relationship between RDW and the main prognostic factorsin HL. We found that patients with sRDW $>0.95$ were significantly older patients, with more advanced disease, with a higher incidence of B-symptoms, with worse ECOG PS, and several worse adverse prognostic factors such as higher erythrocyte sedimentation rate (ESR), lower albumin levels, lower counts of lymphocytes and low hemoglobin $(\mathrm{Hb})$ levels at diagnosis. Multivariate analysis showed that sRDW $>0.95$ was independently associated to patients with anemia $(\mathrm{Hb}<10.5)(\mathrm{RR} 5.9$; CI95\%: 2-16.9; $p=0.001$ ), B-symptoms (RR 2.5; CI95\%: 1.3-4.9; $p=0.007$ ) and low albumin level (RR 2.2; CI95\%: $1.1-4.4 ; p=0.019$ ) (Table 2). 
Table 1. Patients characteristics.

\begin{tabular}{|c|c|c|}
\hline Characteristics & N (\%) & Missing Data \\
\hline Median age (range) & $37(14-83)$ & $0(0 \%)$ \\
\hline Age $\geq 45:$ & $87(32 \%)$ & \multirow{2}{*}{$0(0 \%)$} \\
\hline Age > 60: & $34(13 \%)$ & \\
\hline Sex: $M / F$ & $156(59 \%) / 108(41 \%)$ & $0(0 \%)$ \\
\hline Diagnosis: & & \multirow{7}{*}{$10(4 \%)$} \\
\hline - NS & $183(69 \%)$ & \\
\hline - $\mathrm{MC}$ & $45(17 \%)$ & \\
\hline & $13(5 \%)$ & \\
\hline - LD & $7(3 \%)$ & \\
\hline - Other & $6(2 \%)$ & \\
\hline - Unknown & $10(4 \%)$ & \\
\hline Ann Arbor Stage: & $126(48 \%)$ & \multirow{3}{*}{$0(0 \%)$} \\
\hline - I-II & $\begin{array}{l}126(48 \%) \\
138(52 \%)\end{array}$ & \\
\hline - III-IV & & \\
\hline B-symptoms: & $115(44 \%)$ & $0(0 \%)$ \\
\hline Bulky disease: & $42(16 \%)$ & $1(0 \%)$ \\
\hline ECOG PS: & $190(72 \%)$ & \multirow{3}{*}{$0(0 \%)$} \\
\hline - $0-1$ & $\begin{array}{l}190(/ 2 \%) \\
74(28 \%)\end{array}$ & \\
\hline$->1$ & & \\
\hline ESR: & $99(40 \%)$ & \multirow{3}{*}{$18(7 \%)$} \\
\hline - Normal & $99(40 \%)$ & \\
\hline - High & & \\
\hline Albumin: & & \multirow{3}{*}{$27(10 \%)$} \\
\hline - 40 or more & $117(49 \%)$ & \\
\hline$-\quad<40$ & & \\
\hline Leucocytes $\geq 15,000 / \mu \mathrm{L}$ & $35(13 \%)$ & $0(0 \%)$ \\
\hline Lymphocytes $<600 / \mu$ Lor $<8 \%$ of total leucocytes & $45(17 \%)$ & $0(0 \%)$ \\
\hline $\mathrm{Hb}<10.5 \mathrm{~g} / \mathrm{dL}$ & $61(23 \%)$ & $1(0 \%)$ \\
\hline Median RDW (range) & $13.9(10.6-23.9)$ & $6(2 \%)$ \\
\hline GHSG $>0$ : & $202(79 \%)$ & $10(4 \%)$ \\
\hline EORTC > 0: & $186(73 \%)$ & $10(4 \%)$ \\
\hline IPS: & & \\
\hline$-0-3$ & $\begin{array}{l}214(81 \%) \\
49(19 \%)\end{array}$ & $1(0 \%)$ \\
\hline$->3$ & & \\
\hline
\end{tabular}

NS: nodular sclerosing; MC: mixed cellularity; LR: lymphocyte rich; LD: lymphocyte depleted; ECOG PS: Eastern Cooperative Oncology Group Performance Status; ESR: erythrocyte sedimentation rate; Hb: hemoglobin; RDW: red blood cell distribution width; GHSG: German Hodgkin Study Group; EORTC: European Organization for Research and Treatment of Cancer; IPS: international prognostic score.

\subsection{Response and Survival Analysis}

With frontline therapy, $88 \%$ of the patients reached complete response (CR), $4 \%$ had a partial response (PR), and $8 \%$ a stable/progressive disease (SD/PD). With a median follow-up of 81 months (range, 11-352), six-year event-free survival (EFS) and overall survival (OS) were 74\% (CI95\%: 72-77) and $86 \%$ (C195\%: 84-88), respectively.

Table 3 shows the univariate and multivariate survival analysisin which we included all variables found to be significantin the univariate analysis and sex as a potential confounding factor. Briefly, EFS was significantly influenced by age, AA stage, B-symptoms, ECOG PS, IPS, and all related prognostic factors, excluding sex. Among the alternative inflammatory biomarkers tested: RDW (Figure 2), ESR, 
and RCP were also related to EFS. However, only age $\geq 45$ years, sRDW $>0.95$, and the presence of lymphopenia were independently associated with a worse EFS. CR tended to be higherin patients with sRDW $\leq 0.95: 92 \%$ vs. $84 \%(p=0.051)$.

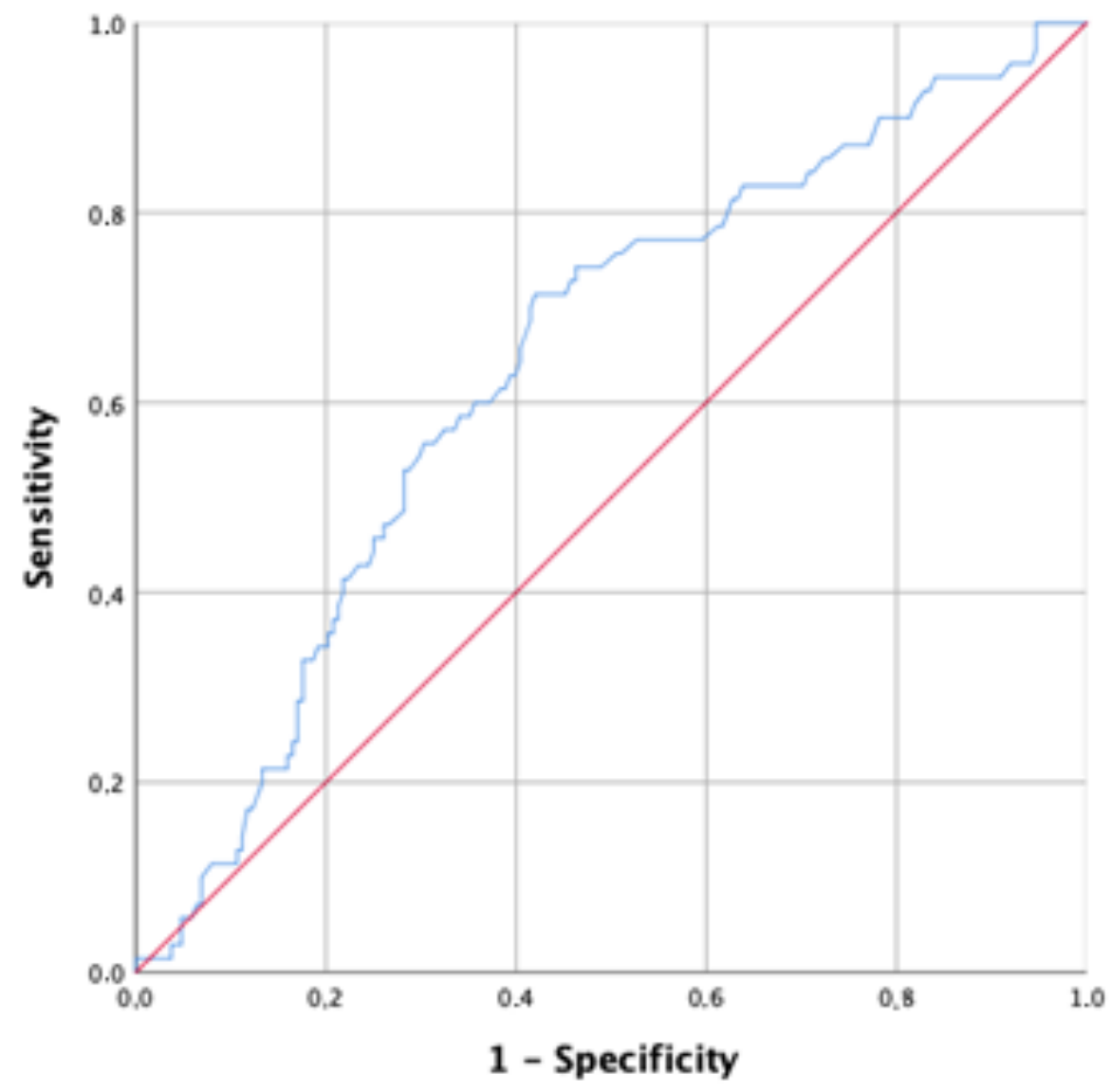

Figure 1. ROC analysis about the prognostic role of RDW on progression or death of any cause.

Table 2. Analysis of the relationship of RDW and main prognostic factors in HL.

\begin{tabular}{cccc}
\hline Characteristics & sRDW 0-0.95 & sRDW $>0.95$ & $P$ \\
\hline Median age (range) & $33(14-83)$ & $40(15-83)$ & 0.014 \\
\hline Sex: M/F & $70(54 \%) / 59(46 \%)$ & $82(64 \%) / 47(36 \%)$ & 0.16 \\
\hline Ann Arbor Stage III-IV & $42(33 \%)$ & $93(72 \%)$ & $<0.001$ \\
\hline B-symptoms: & $30(23 \%)$ & $83(64 \%)$ & $<0.001$ \\
\hline Bulky disease: & $19(15 \%)$ & $21(16 \%)$ & 0.86 \\
\hline ECOG PS $>1$ & $24(19 \%)$ & $49(38 \%)$ & 0.001 \\
\hline Elevated ESR: & $45(39 \%)$ & $100(80 \%)$ & $<0.001$ \\
\hline Albumin $<40:$ & $33(29 \%)$ & $86(72 \%)$ & $<0.001$ \\
\hline Leucocytes $\geq 15,000 / \mu \mathrm{L}$ & $12(9 \%)$ & $22(17 \%)$ & 0.097 \\
\hline $\begin{array}{c}\text { Lymphocytes }<600 / \mu \mathrm{L} \text { or }<8 \% \\
\text { of total leucocytes }\end{array}$ & $7(5 \%)$ & $37(29 \%)$ & $<0.001$ \\
\hline Hb $<10.5 \mathrm{~g} / \mathrm{dL}$ & $6(5 \%)$ & $55(43 \%)$ & $<0.001$ \\
\hline IPS $>3$ & $1(1 \%)$ & $47(37 \%)$ & $<0.001$ \\
\hline
\end{tabular}

sRDW: standardized red blood cell distribution width; M/F: male/female; ECOG PS: Eastern Cooperative Oncology Group Performance Status; ESR: erythrocyte sedimentation rate; Hb: hemoglobin; IPS: international prognostic score. 
Table 3. Univariate and multivariate survival analysis for EFS and OS.

\begin{tabular}{|c|c|c|c|c|}
\hline \multicolumn{5}{|c|}{ Univariate Analysis } \\
\hline Factor & 6-year EFS (95\% CI) & $p$ & 6-year OS (95\% CI) & $P$ \\
\hline $\begin{array}{c}\text { Age: } \\
-\quad 14-44 \\
-\quad \geq 45\end{array}$ & $\begin{array}{l}80 \%(74-86) \\
63 \%(51-74)\end{array}$ & 0.005 & $\begin{array}{l}93 \%(90-97) \\
70 \%(59-81)\end{array}$ & $<0.001$ \\
\hline $\begin{array}{c}\text { Age: } \\
-\quad 14-60 \\
-\quad>60\end{array}$ & $\begin{array}{l}78 \%(72-83) \\
46 \%(46-11)\end{array}$ & 0.002 & $\begin{array}{l}90 \%(86-94) \\
54 \%(32-76)\end{array}$ & $<0.001$ \\
\hline $\begin{array}{c}\text { Sex: } \\
\text { - } \quad \text { Male } \\
-\quad \text { Female }\end{array}$ & $\begin{array}{l}75 \%(68-82) \\
74 \%(65-83)\end{array}$ & 0.33 & $\begin{array}{l}\text { 85\% (79-91) } \\
87 \% \text { (80-95) }\end{array}$ & 0.1 \\
\hline $\begin{array}{c}\text { Ann Arbor stage: } \\
-\quad \text { I-II } \\
-\quad \text { III-IV }\end{array}$ & $\begin{array}{l}83 \%(76-90) \\
67 \%(58-75)\end{array}$ & 0.002 & $\begin{array}{l}91 \%(85-96) \\
81 \%(74-89)\end{array}$ & 0.1 \\
\hline $\begin{array}{l}\text { B symptoms: } \\
\text { - No } \\
-\quad \text { Yes }\end{array}$ & $\begin{array}{l}82 \%(75-88) \\
65 \%(55-75)\end{array}$ & 0.001 & $\begin{array}{l}89 \%(83-94) \\
82 \%(74-90)\end{array}$ & 0.031 \\
\hline $\begin{array}{l}\text { ECOG PS: } \\
-\quad 0-1 \\
-\quad 2-4\end{array}$ & $\begin{array}{l}78 \%(72-84) \\
65 \%(51-79)\end{array}$ & 0.002 & $\begin{array}{l}88 \%(83-92) \\
76 \%(62-90)\end{array}$ & 0.007 \\
\hline $\begin{array}{c}\text { IPS: (All stages) } \\
-\quad 0-3 \\
-\quad>3\end{array}$ & $\begin{array}{l}78 \%(72-84) \\
58 \%(43-74)\end{array}$ & 0.002 & $\begin{array}{l}88 \%(83-92) \\
77 \%(64-91)\end{array}$ & 0.008 \\
\hline $\begin{array}{c}\text { IPS: (Advanced HL) } \\
-\quad 0-3 \\
-\quad>3\end{array}$ & $\begin{array}{l}68 \%(58-79) \\
62 \%(47-78)\end{array}$ & 0.26 & $\begin{array}{l}83 \%(74-92) \\
77 \%(63-92)\end{array}$ & 0.072 \\
\hline $\begin{array}{l}\text { ESR: } \\
\text { - } \quad \text { Normal } \\
\text { - } \quad \text { High }\end{array}$ & $\begin{array}{l}82 \%(75-90) \\
68 \%(60-77)\end{array}$ & 0.003 & $\begin{array}{l}90 \%(84-96) \\
83 \%(76-90)\end{array}$ & 0.079 \\
\hline $\begin{array}{l}\text { CRP: } \\
\text { - } \quad \text { Normal } \\
-\quad \text { High }\end{array}$ & $\begin{array}{l}89 \%(79-99) \\
68 \%(60-77)\end{array}$ & 0.005 & $\begin{array}{c}95 \%(87-100) \\
83 \%(76-90)\end{array}$ & 0.047 \\
\hline $\begin{array}{r}\text { sRDW: } \\
-\quad \leq 0.95 \\
-\quad>0.95\end{array}$ & $\begin{array}{l}86 \%(80-92) \\
63 \%(54-72)\end{array}$ & $<0.001$ & $\begin{array}{l}94 \%(90-98) \\
78 \%(70-86)\end{array}$ & 0.001 \\
\hline $\begin{aligned} & \text { B2M: } \\
- & \text { Normal } \\
- & \text { High }\end{aligned}$ & $\begin{array}{l}80 \%(73-87) \\
63 \%(52-75)\end{array}$ & 0.003 & $\begin{array}{l}94 \%(90-98) \\
74 \%(63-84)\end{array}$ & $<0.001$ \\
\hline $\begin{array}{l}\text { Albumin: } \\
-\quad \geq 40 \\
-\quad<40\end{array}$ & $\begin{array}{l}84 \%(77-91) \\
66 \%(57-76)\end{array}$ & 0.001 & $\begin{array}{l}93 \%(87-98) \\
83 \%(76-91)\end{array}$ & 0.02 \\
\hline $\begin{array}{l}\text { Leucocytes: } \\
-\quad<15000 \\
-\quad \geq 15000\end{array}$ & $\begin{array}{l}77 \%(71-83) \\
58 \%(41-75)\end{array}$ & 0.006 & $\begin{array}{l}87 \%(82-92) \\
80 \%(66-93)\end{array}$ & 0.13 \\
\hline 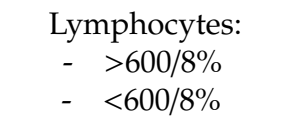 & $\begin{array}{l}80 \%(74-85) \\
48 \%(32-65)\end{array}$ & $<0.001$ & $\begin{array}{l}89 \%(88-95) \\
68 \%(52-85)\end{array}$ & $<0.001$ \\
\hline $\begin{array}{l}\mathrm{Hb}: \\
-\quad \geq 10.5 \\
-\quad<10.5\end{array}$ & $\begin{array}{l}81 \%(75-87) \\
51 \%(37-66)\end{array}$ & $<0.001$ & $\begin{array}{l}88 \%(83-93) \\
79 \%(68-91)\end{array}$ & 0.044 \\
\hline
\end{tabular}


Table 3. Cont.

\begin{tabular}{ccccc}
\hline \multicolumn{5}{c}{ Multivariate Analysis } \\
\hline PFS & $\mathrm{p}$ & HR $(95 \%$ CI $)$ & $\mathrm{P}$ \\
\hline Factor & HR $(95 \% \mathrm{CI})$ & $2.7(1.2-5.7)$ & 0.013 \\
\hline Lymphocytes $<600 / 8 \%$ & $2.2(1.3-4)$ & 0.006 & $3(1.1-8.1)$ & 0.027 \\
\hline RDW $>0.95$ & $2.3(1.2-4.3)$ & 0.007 & $5.7(2.6-12.5)$ & $<0.001$ \\
\hline Age $\geq 45$ & $1.8(1.1-3)$ & 0.022 & $2.5(1-6.1)$ & 0.049 \\
\hline Male sex & - & - &
\end{tabular}

EFS: event-free survival; OS: overall survival; ECOG PS: Eastern Cooperative Oncology Group Performance Status; IPS: international prognostic score; ESR: erythrocyte sedimentation rate; CRP: C reactive protein; sRDW: standardized red blood cell distribution width; B2M: B2microglobulin; Hb: hemoglobin.

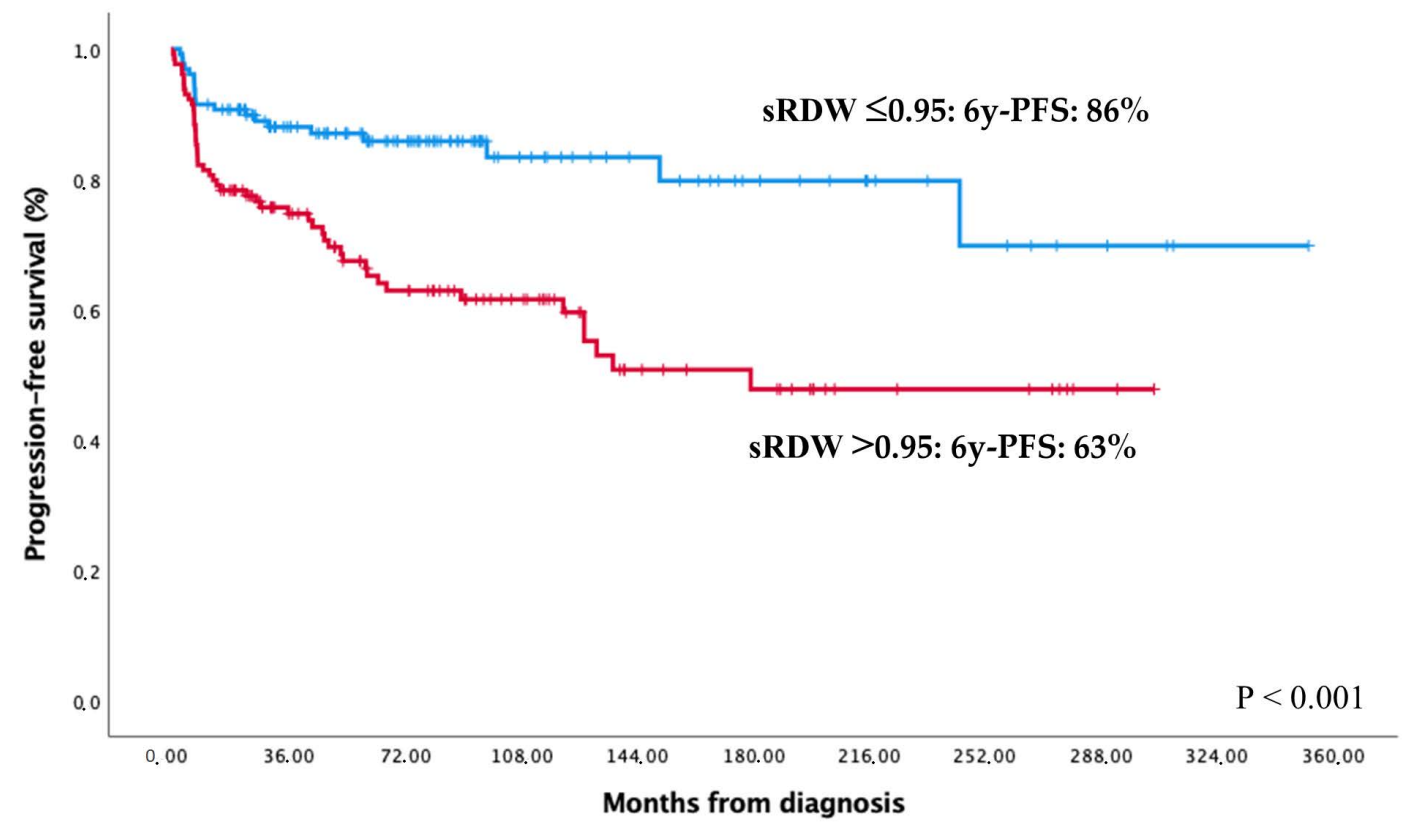

Figure 2. Progression-free and overall survival according to sRDW.

In the case of OS, univariate analysis showed the influence of age, B-symptoms, ECOG PS, IPS, and all related factors, excluding sex and leucocytes. Regarding alternative inflammatory biomarkers, only CRP and sRDW seemed to significantly influence OS. Multivariate analysis found the same three prognostic factors (age $\geq 45$ years, sRDW $>0.95$, and lymphopenia) independently associated with a worse OS, together with the male sex, that was includedin the analysis as a potential confounding variable (Table 3).

Furthermore, the long-term incidence of second malignancies was significantly higherin patients with sRDW $>0.95$ : $15(12 \%)$ vs. $4(3 \%)(p=0.015)$. Particularly, the incidence of lung cancer was much higher ( $5 \%$ vs. $1 \%$ )in patients with sRDW > 0.95 (Table 4$)$. Unfortunately, the low incidence of specific secondary malignancies does not allow us to draw more definitive conclusions regarding the specific role of sRDW or other factorsin the incidence of each type of malignancy. While anecdotal, all three patients with head and neck malignancies were previously treated with radiotherapy (2 with sRDW $\leq 0.95)$.

Using binary logistic regression, we studied the prognostic factors related to the incidence of secondary malignancies. In the univariate analysis we observed a significantly higher risk of secondary malignanciesin older patients $(p=0.013)$, with $\mathrm{Hb}<10.5 \mathrm{~g} / \mathrm{dL}(p=0.013)$, and sRDW $>0.95$ $(p=0.014)$, but not radiotherapy administration $(p=0.15)$. However, we performed a multivariate analysis including all significant prognostic factors from the univariate analysis as well as radiotherapy 
as a potential confounding factor, and we found that only older age (RR: $1.03 ; p=0.018)$, sRDW $>0.95$ (RR: $3.84 ; p=0.047$ ) and radiotherapy administration (RR: 3.81; $p=0.014$ ) were independently related to a higher incidence of secondary malignancies.

Table 4. RDW and incidence of second malignancies.

\begin{tabular}{cccc}
\hline & sRDW $\leq \mathbf{0 . 9 5}$ & sRDW $>\mathbf{0 . 9 5}$ & $p$ \\
\hline Second malignancies & $4(3.1 \%)$ & $15(11.6 \%)$ & 0.015 \\
\hline Lung cancer & $1(0.8 \%)$ & $7(5.4 \%)$ & \\
Head and neck & $2(1.6 \%)$ & $1(0.8 \%)$ & 0.02 \\
Other & $1(0.8 \%)$ & $7(5.4 \%)$ & \\
\hline
\end{tabular}

sRDW: standardized red blood cell distribution width.

\section{Discussion}

To our knowledge, this is the first published report about the main prognostic role of RDWin HL. We previously presented part of this data at the 58th Annual Meeting of the American Society of Hematology [25]. In our study, RDW strongly correlated with main prognostic factorsin HL, and sRDW $>0.95$ is shown to be an independent adverse prognostic factor for EFS and OS.

RDW is an automatically measured index of the heterogeneity of the erythrocytes [4]. Traditionally, this parameter was used for the differential diagnosis of anemias [26]. In cancer, anemia could be present due to inflammation, and after treatment [27].

Physiological conditions that could increase the RDW levels include aging, erythropoietin, pregnancy, black ethnicity, and physical exercise [13]. In previous years, an increasein RDW levels was described as an adverse prognostic factor that increases mortalityin the general population, associated with many acute and chronic conditions, in which inflammation represents a critical factor, including metabolic, cardiovascular, and thrombotic disorders [13].

RDW,in cancer, reflects chronic inflammation and poor nutritional status [28]. Certain studies support that cytokines play a central rolein RDW, being associated with advanced stages and higher mortality. It has been related to different inflammatory markers such as interleukin-6, ESR, CRP, soluble tumor necrosis factor receptors I and II, and soluble transferrin receptor [12]. Elevated levels of proinflammatory cytokines led to inadequate production of erythropoietin, impaired erythrocyte maturation, a poor nutritional status (hypoalbuminemia), and increased levels of hepcidin and oxidative stress. These are different biological mechanisms that may lead to higher values of RDW [28].

RDW has been shown to confer a worse prognosisin many types of hematological malignancies, including lymphoproliferative and myeloproliferative disorders. In aggressive lymphomas, such as DLBCL, elevated levels of RDW at diagnosis were associated with worse ECOG PS, B-symptoms, and higher IPI. They predicted a poorer prognosis [15,22]. It has been described as an independent adverse prognostic factor at diagnosisin MCL, and RDW also improved the prognostic stratification based on the simplified Mantle Cell International Prognostic Index (sMIPI) [16]. In extranodal NK/T nasal-type lymphoma, high RDW at diagnosis has been associated with poorer clinical outcomesin patients treated with radiotherapy-based schedules [29].

In indolent lymphoproliferative disorders, such as multiple myeloma, RDW at diagnosis has been described to predict the outcome and correlate with response to therapy [17-19,21]. Furthermore,in CLL, elevated RDW levels at diagnosis were associated with adverse prognostic factors such as advanced disease [14]. In hairy cell leukemia, high RDW was associated with active disease both at diagnosis and after receiving treatment [30].

Regarding myeloid malignancies, a prognostic role at diagnosis has been describedin chronic myeloid leukemia as a biomarker for risk stratification and its ability to predict response to treatment [31]. In myelodysplastic syndromes, high RDW valuesin patients with less than $5 \%$ blasts at diagnosis, was an independent prognostic factor. Approximately 30\% of patients classified as IPSS-R lower-risk showed similar outcomes to those with higher-risk IPSS-R [32,33]. 
Most variables independently influencing PFS and OS detect HL's immune relationships (sRDW $>0.95$, lymphopenia and older age). RDW is more related to systemic inflammation, while lymphopenia may be more associated with immune dysfunction. Older age may be related to both situations.

In our series, we found a strong relationship between RDW and most prognostic factorsin HL. Multivariate analysis showed that a higher RDW was independently associated with anemia, higher CPR, and low albumin. However, the most important characteristic of RDW is that it is a cheap and easily available prognostic factor that may be obtained from automatic blood cell counts at the time of diagnosis.

More importantly, RDW was independently associated with EFS and OS. We also found a relationship with the long-term development of secondary malignancies, a critical adverse prognostic factorin a malignancy such as HL with good long-term survival. RDW is increasedin patients with a higher proinflammatory background, more prone to adverse events, and shorter PFS as well as with a higher incidence of cancer in general.

Some of the present study's limitations include a retrospective analysis performedin two different centers over almost 30 years. However, we tried to minimize these limitations by using a significant sample $(n=264)$ without selection bias, homogenously treated (ABVD), and by standardizing the RDW values.

\section{Materials and Methods}

\subsection{Patients and Sample Selection}

We selected patients with classic HL homogeneously treated with ABVD (adriamycin, bleomycin, vinblastine, and dacarbazine) +/- radiotherapy (RT) at Son Espases and Son Llatzer University Hospitalsin the Balearic Islands, between 1990 and 2018. To avoid selection bias, we selected patients from the databases of the Services of Pathology and Pharmacy. Those patients treated with different schemes were excluded. This study was approved by the Ethics Committee of the Balearic Islands with the number IB4071/19.

\subsection{Clinical and Laboratory Prognostiz Factors}

Clinical variables were obtained from medical records including main prognostic factorsin main prognostic indexesin HL: age, gender, Ann Arbor Stage, lactate dehydrogenase (LDH) and $\beta-2$ microglobulin (B2M) serum levels, extranodal sites, B-symptoms, Eastern Cooperative Oncology Group performance status (ECOG PS), bulky disease and main variables of automated blood counts. As RDW values have been obtained using different techniques and measurement systemsin different centers and periods, we standardized them using the normal reference values of each determination, generating a standardized RDW (sRDW).

Main prognostic scores, International Prognostic Score (IPS), and those from the European Organization for Research and Treatment of Cancer (EORTC) and the German Hodgkin Lymphoma Study Group (GHSG) were calculated. Response assessment was done using Cheson [34] or Lugano criteria [35]in the corresponding time periods.

\subsection{Statistical Methods}

Qualitative or binomial variables were expressed as frequencies and percentages. Comparisons between qualitative variables were made using the Fisher Exact Test or Chi-square. Comparisons between quantitative and qualitative variables were performed through non-parametric tests (U of Mann-Whitney or Kruskal-Wallis). Receiver operating curve (ROC) analysis was used to obtain and optimal sRDW cutoff for progression or death of any cause. The binary logistic regression was used to find out the risk factors associated with sRDW and those associated with a higher risk of secondary malignancies. 
Time to event variables were estimated according to the Kaplan-Meier method, and the log-rank test performed comparisons between variables of interest. Multivariate analysis with the variables that were significantin the univariate analysis and potential confounding factors was carried out according to the Cox proportional hazard regression model. A backward stepwise Cox multivariate analysis was performed to determine factors independently associated with PFS and OS. All $p$ values reported were 2 -sided, and statistical significance was defined at $p<0.05$. Statistical analysis was performed using a statistical package program (SPSS Inc, Chicago, IL, USA).

\section{Conclusions}

In conclusion, we report for the first time that RDW is a simple, cheap, and easily available prognostic factorin $\mathrm{HL}$, that identifies a group with worse EFS, OS, and a higher potential incidence of secondary malignancies. RDW seems to be related to most adverse prognostic factorsin HL, making RDW an excellent candidate to be includedin prognostic scores for HL. We are currently exploring new prognostic scoresin HL including variables easy to obtain from the automated blood counts, such as RDW.

Author Contributions: A.G. and I.H. performed the research. L.B., R.D.C., A.S. (Adriana Sas), R.R., J.I., F.M., J.B. and A.S. (Antonia Sampol) contributed to clinical data. A.G. and I.H. performed the statistical analysis and data interpretation. R.A. revised the methodology. All authors contributed to reviewing, provided their comments on this manuscript, and approved the final version. All authors have read and agreed to the published version of the manuscript.

Funding: This research received no external funding.

Conflicts of Interest: The authors declare no conflict of interest.

\section{References}

1. Shanbhag, S.; Ambinder, R.F. Hodgkin lymphoma: A review and update on recent progress. CA Cancer. J. Clin. 2017, 68, 116-132. [CrossRef]

2. Cuccaro, A.; Bartolomei, F.; Cupelli, E.; Hohaus, S.; Galli, E.; Giachelia, M. Prognostic factorsin hodgkin lymphoma. Mediterr. J. Hematol. Infect. Dis. 2014, 6, e2014053. [CrossRef] [PubMed]

3. LaCasce, A.S. Treating Hodgkin lymphomain the new millennium: Relapsed and refractory disease. Hematol. Oncol. 2019, 37, 87-91. [CrossRef]

4. Montagnana, M.; Danese, E. Red cell distribution width and cancer. Ann. Transl. Med. 2016, 4, 399. [CrossRef]

5. Ai, L.; Mu, S.; Hu, Y. Prognostic role of RDWin hematological malignancies: A systematic review and meta-analysis. Cancer Cell Int. 2018, 18, 61. [CrossRef]

6. Huang, D.-P.; Ma, R.-M.; Xiang, Y.-Q. Utility of Red Cell Distribution Width as a Prognostic Factorin Young Breast Cancer Patients. Medicine 2016, 95, e3430. [CrossRef]

7. Koma, Y.; Onishi, A.; Matsuoka, H.; Oda, N.; Yokota, N.; Matsumoto, Y.; Koyama, M.; Okada, N.; Nakashima, N.; Masuya, D.; et al. Increased Red Blood Cell Distribution Width Associates with Cancer Stage and Prognosisin Patients with Lung Cancer. PLoS ONE 2013, 8, e80240. [CrossRef] [PubMed]

8. Zhao, T.; Cui, L.; Li, A. The significance of RDWin patients with hepatocellular carcinoma after radical resection. Cancer Biomark. 2016, 16, 507-512. [CrossRef] [PubMed]

9. Weitzman, D.; Raz, R.; Steinvil, A.; Zeltser, D.; Berliner, S.; Chodick, G.; Shalev, V.; Arbel, Y. Red blood cell distribution width and the risk of cardiovascular morbidity and all-cause mortality. Thromb. Haemost. 2014, 111, 300-307. [CrossRef] [PubMed]

10. Ay, S.; Eryilmaz, M.A.; Aksoy, N.; Okus, A.; Unlu, Y.; Sevinc, B. Is Early Detection of Colon Cancer Possible with Red Blood Cell Distribution Width? Asian Pac. J. Cancer Prev. 2015, 16, 753-756. [CrossRef] [PubMed]

11. Riedl, J.; Posch, F.; Königsbrügge, O.; Lötsch, F.; Reitter, E.-M.; Eigenbauer, E.; Marosi, C.; Schwarzinger, I.; Zielinski, C.C.; Pabinger, I.; et al. Red Cell Distribution Width and Other Red Blood Cell Parametersin Patients with Cancer: Association with Risk of Venous Thromboembolism and Mortality. PLoS ONE 2014, 9, e111440. [CrossRef] [PubMed] 
12. Banfi, G.; Targher, G.; Montagnana, M.; Salvagno, G.L.; Zoppini, G.; Guidi, G.C. Relation between red blood cell distribution width and inflammatory biomarkersin a large cohort of unselected outpatients. Arch. Pathol. Lab. Med. 2009, 133.

13. Salvagno, G.L.; Sanchis-Gomar, F.; Picanza, A.; Lippi, G. Red blood cell distribution width: A simple parameter with multiple clinical applications. Crit. Rev. Clin. Lab. Sci. 2014, 52, 86-105. [CrossRef] [PubMed]

14. Podhorecka, M.; Halicka, D.; Szymczyk, A.; Macheta, A.; Chocholska, S.; Hus, M.; Darzynkiewicz, Z. Assessment of red blood cell distribution width as a prognostic markerin chronic lymphocytic leukemia. Oncotarget 2016, 7, 32846-32853. [CrossRef]

15. Zhou, S.; Fang, F.; Chen, H.; Zhang, W.; Chen, Y.; Shi, Y.; Zheng, Z.; Ma, Y.; Tang, L.; Feng, J.; et al. Prognostic significance of the red blood cell distribution widthin diffuse large B-cell lymphoma patients. Oncotarget 2017, 8, 40724-40731. [CrossRef] [PubMed]

16. Miao, Y.; Zhou, X.-H.; Guo, J.-J.; Sun, Q.; Shi, K.; Wu, J.; Zhu, H.; Wang, L.; Fan, L.; Xu, W.; et al. Association of red blood cell distribution width and outcomesin patients with mantle cell lymphoma. Cancer Med. 2019, 8, 2751-2758. [CrossRef]

17. Meng, S.; Ma, Z.; Lu, C.; Liu, H.; Tu, H.; Zhang, W.-G.; Zhou, F. Prognostic Value of Elevated Red Blood Cell Distribution Widthin Chinese Patients with Multiple Myeloma. Ann. Clin. Lab. Sci. 2017, 47, 282-290.

18. Zhou, D.; Xu, P.; Peng, M.; Shao, X.; Wang, M.; Ouyang, J.; Chen, B. Pre-treatment red blood cell distribution width provides prognostic informationin multiple myeloma. Clin. Chim. Acta 2018, 481, 34-41. [CrossRef]

19. Lee, H.; Kong, S.-Y.; Sohn, J.Y.; Shim, H.; Youn, H.S.; Lee, S.; Kim, H.J.; Eom, H.-S. Elevated Red Blood Cell Distribution Width as a Simple Prognostic Factorin Patients with Symptomatic Multiple Myeloma. BioMed Res. Int. 2014, 2014, 1-8. [CrossRef]

20. Chen, Y.-P.; Zhang, W.-N.; Chen, L.; Tang, L.-L.; Mao, Y.-P.; Li, W.-F.; Liu, X.; Zhou, G.-Q.; Sun, Y.; Kang, T.-B.; et al. Effect of latent membrane protein 1 expression on overall survivalin Epstein-Barr virus-associated cancers: A literature-based meta-analysis. Oncotarget 2015, 6, 29311-29323. [CrossRef]

21. Ma, Y.; Jin, Z.; Zhou, S.; Ye, H.; Jiang, S.; Yu, K. Prognostic significance of the red blood cell distribution width that maintain at high level following completion of first line therapyin mutiple myeloma patients. Oncotarget 2018, 9, 10118-10127. [CrossRef]

22. Periša, V.; Zibar, L.; Sinčić-Petričević, J.; Knezovic, A.; Periša, I.; Barbić, J. Red blood cell distribution width as a simple negative prognostic factorin patients with diffuse large B-cell lymphoma: A retrospective study. Croat. Med. J. 2015, 56, 334-343. [CrossRef]

23. Bento, L.; Díaz-López, A.; Barranco, G.; Martín-Moreno, A.M.; Baile, M.; Martín, A.; Sancho, J.M.; García, O.; Rodríguez, M.; Sánchez-Pina, J.M.; et al. New prognosis score including absolute lymphocyte/monocyte ratio, red blood cell distribution width and beta-2 microglobulinin patients with diffuse large B-cell lymphoma treated with R-CHOP: Spanish Lymphoma Group Experience (GELTAMO). Br. J. Haematol. 2019, 188, 888-897. [CrossRef]

24. Li, M.; Xia, H.; Zheng, H.; Li, Y.; Liu, J.; Hu, L.; Li, J.; Ding, Y.; Pu, L.; Gui, Q.; et al. Red blood cell distribution width and platelet counts are independent prognostic factors and improve the predictive ability of IPI scorein diffuse large B-cell lymphoma patients. BMC Cancer 2019, 19, 1084. [CrossRef]

25. Andrade, B.L.; Robredo, B.; Sartori, F.; Herráez, I.; Pastor, M.A.D.; Recio, M.G.; Serra, J.J.M.; Bento, L.; Sampol, A.; Rodríguez, J.; et al. Red Cell Distribution Width (RDW) at Diagnosis Is Associated to Advanced Stage, Worse Response and Poor Prognosisin Hodgkin Lymphoma. Blood 2016, 128, 5373. [CrossRef]

26. Weiss, G.; Goodnough, L.T. Anemia of Chronic Disease. N. Engl. J. Med. 2005, 352, 1011-1023. [CrossRef]

27. Macciò, A.; Madeddu, C.; Gramignano, G.; Mulas, C.; Tanca, L.; Cherchi, M.C.; Floris, C.; Omoto, I.; Barracca, A.; Ganz, T. The role of inflammation, iron, and nutritional statusin cancer-related anemia: Results of a large, prospective, observational study. Haematologica 2014, 100, 124-132. [CrossRef]

28. Wang, P.-F.; Song, S.-Y.; Guo, H.; Wang, T.-J.; Liu, N.; Yan, C.-X. Prognostic role of pretreatment red blood cell distribution widthin patients with cancer: A meta-analysis of 49 studies. J. Cancer 2019, 10, 4305-4317. [CrossRef]

29. Luo, H.; Quan, X.; Song, X.-Y.; Zhang, L.; Yin, Y.; He, Q.; Cai, S.; Li, S.; Zeng, J.; Zhang, Q.; et al. Red blood cell distribution width as a predictor of survivalin nasal-type, extranodal natural killer/T-cell lymphoma. Oncotarget 2017, 8, 92522-92535. [CrossRef] [PubMed] 
30. Chrobák, L.; Žák, P.; Podzimek, K.; Stránský, P. Red Cell Distribution Width (RDW) as a Marker of Disease Activityin Patients with Hairy Cell Leukemia. Acta Med. (Hradec Kralove, Czech Republic) 1998, 41, $23-26$. [CrossRef]

31. Iriyama, N.; Hatta, Y.; Kobayashi, S.; Uchino, Y.; Miura, K.; Kurita, D.; Kodaira, H.; Takahashi, H.; Iizuka, Y.; Inoue, M.; et al. Higher Red Blood Cell Distribution Width Is an Adverse Prognostic Factorin Chronic-phase Chronic Myeloid Leukemia Patients Treated with Tyrosine Kinase Inhibitors. Anticancer Res. 2015, 35, 5473-5478.

32. Shi, Z.; Li, B.; Huang, H.; Qin, T.; Xu, Z.; Zhang, H.; Fang, L.; Pan, L.; Hu, N.; Qu, S.; et al. Prognostic impact of red blood cell distribution widthin myelodysplastic syndromes. Br. J. Haematol. 2019, 186, 352-355. [CrossRef] [PubMed]

33. Rauw, J.; Wells, R.; Chesney, A.; Reis, M.; Zhang, L.; Buckstein, R. Validation of a scoring system to establish the probability of myelodysplastic syndromein patients with unexplained cytopenias or macrocytosis. Leuk. Res. 2011, 35, 1335-1338. [CrossRef]

34. Cheson, B.D.; Horning, S.J.; Coiffier, B.; Shipp, M.A.; Fisher, R.I.; Connors, J.M.; Lister, T.A.; Vose, J.; Grillo-López, A.; Hagenbeek, A.; et al. Report of an International Workshop to Standardize Response Criteria for Non-Hodgkin's Lymphomas. J. Clin. Oncol. 1999, 17, 1244. [CrossRef]

35. Cheson, B.D.; Fisher, R.I.; Barrington, S.F.; Cavalli, F.; Schwartz, L.H.; Zucca, E.; Lister, T.A. Recommendations for Initial Evaluation, Staging, and Response Assessment of Hodgkin and Non-Hodgkin Lymphoma: The Lugano Classification. J. Clin. Oncol. 2014, 32, 3059-3067. [CrossRef]

Publisher's Note: MDPI stays neutral with regard to jurisdictional claims in published maps and institutional affiliations. 